\title{
Studies on changes in lipid profiles of new varieties of rape during seed maturation
}

\author{
By Safinaz M. El-Shami, Minar M.M. Hassanein and M. Hassan El-Mallah
}

National Research Centre, Fats and Oils Res. Lab.

Dokki, Cairo, Egypt

\section{RESUMEN}

Estudio de los cambios en perfiles lipídicos de nuevas variedades de colza durante la maduración de la semilla.

Se estudiaron los cambios en los lípidos de tres nuevas variedades desarrolladas de colza durante la maduración de la semiIla. Las especies moleculares de triacilgliceroles, la composición en ácidos grasos, los esteroles totales, y cuatro esteroles lipídicos, así como tocoferol fueron determinados en diversas etapas de maduración.

Se encontraron variaciones más marcadas en algunos lípidos en una variedad que en las otras. Los eficientes métodos de análisis empleados en esta investigación permitieron detectar con exactitud, incluso en cantidades muy pequeñas los componentes lipídicos individuales. Los cambios varietales marcados en las composiciones lipídicas se manifiestaron durante la maduración de la semilla en tres nuevas variedades de colza. Los cambios en lípidos de semillas durante la maduración fueron interpretados en el marco de las probables reacciones de conversión-interconversión que pueden ocurrir durante la maduración de la semilla.

PALABRAS-CLAVE: Colza - Maduración - Perfil lipídico Semilla.

\section{SUMMARY}

Studies on changes in lipid profiles of new varieties of rape during seed maturation.

Changes in lipids of three newly developed varieties of rapeseed during seed maturation were studied. Triacylglycerol molecular species, fatty acid composition, whole sterol, and four sterol lipids as well as tocopherol were determined at different maturation stages.

It was found that marked variations in some lipids were observed in one variety than the other. Efficient methods of analysis employed in this investigation and the individual lipid components, even in very minor quantities, were accurately detected. Marked varietal changes in lipids compositions during seed maturation manifest themselves, to some extent, in three new rapeseed varieties. Changes in lipids of maturing seeds were interpreted in the frame of probable conversion-interconversion reactions that may occur during seed maturation.

KEY-WORDS: Lipid profile - Maturation - Rape - Seed.

\section{INTRODUCTION}

Oilseed crops are considered as strategic sources for edible oils and accordingly, extensive work has been carried out on oilseed composition particularly during maturation (1-25). Rapeseed oil crop has also received the interest of many investigators (25-31)during seed development. In addition, the influence of temperature during seed development on fatty acid composition of oilseed rape was studied in one low-linolenic acid and one conventional cultivar (26).

Newly developed varieties of rapeseed (Brassica napus) were locally cultivated in Experimental Agricultural Station, National Research Centre, however chemical constitution of their lipids, have not been hitherto determined. Thus, the main objective of this work was to follow compositional changes of triacylglycerol, fatty acids, sterols, sterol esters, sterylglycosides and tocopherol in these new varieties.

It was also planned to interpret changes in lipids components in maturing seeds, in the frame of the probable lipid conversion reactions that may occur during maturation process. High-efficiency HPLC and GLC methods of analysis are also adopted to help detect the different lipid components even they are in minute quantities.

\section{MATERIALS AND METHODS}

\subsection{Materials}

Three varieties of rapeseeds (Brassica napus) were cultivated in the Experimental Agricultural Station of the National Research Centre of Egypt (season 1997-1998).

These varieties, namely, semu DNK 65/84, 53 and semu DNK 201/85 are designated VA, VB and VC respectively and they are genetically different. Seeds were cultivated at 15-11-1997 and the seeds were collected at 65, 80 and 95 days after flowering (DAF).

\subsection{Methods}

A representative sample of seeds $(100 \mathrm{~g})$ was extracted with chloroform-methanol ( $2: 1$ by volume) in a warning Blender. The extract was dried over anhydrous sodium sulphate and the solvent was 
removed from the filtrate using a rotary evaporator under reduced pressure at $40^{\circ} \mathrm{C}$.

The lipid patterns, namely, fatty acids (FA), triacylglycerol (TAG), tocopherols (T), whole oil sterols and sterol lipids, namely, free sterols (FS), acylated sterols (AS), free sterylglycosides (FSG) and acylated sterylglycosides (ASG) were determined. All HPLC and GLC data recorded in the tables were the mean of two concordant replicates. In addition the methods were calibrated using authentic compounds to obtain higher accuracy.

\section{A. Fatty Acid Pattern}

The oil was converted into methyl esters, via transesterification, with $5 \%$ methanolic hydrogen chloride $(18,32)$. Transesterification reaction was monitored with the help of TLC using silica gel G plates and n-hexane:diethyl ether:acetic acid (80:20:1 by Volume) as a developing solvent.

Hewlett Packard-HP 5890-A gas chromatograph was employed for, the analysis of the mixed methyl esters under the following operating conditions: column, DB-23 $(0.32 \mathrm{~mm} \times 30 \mathrm{~m})$; temperature programming, $150-230^{\circ} \mathrm{C}, 3^{\circ} \mathrm{C} / \mathrm{min}$; injector, $230^{\circ} \mathrm{C}$; detector, FID at $240^{\circ} \mathrm{C}$; carrier gas, Helium at flow rate of $1.3 \mathrm{ml} / \mathrm{min}$. and split ratio, 100:1.

Calibration was made using standard fatty acid methyl esters. The results were recorded by an electronic integrator as peak area per cent.

\section{B. Triacylglycerol Profile}

HPLC instrument (Toyo-Soda-CCPM) was employed for the determination of triacylglycerol (TAG) profiles of the rapeseed oils. A $10 \mu$ l solution of oil in chloroform $(300 \mathrm{mg} / \mathrm{ml})$ was injected onto the column, ODS capcel Pak, $\mathrm{C}_{18}(4.4$ x $100 \mathrm{~mm})$. Gradient elution with acetonitrile : dichloromethane (starting from 90:10 to 35:65 v/v) in 150 minute was conducted. FID detector (with moving band, Tracor 945) was attached to the instrument $\mu$ l.

The carbon number assignment for the separated peaks was determined using HPLC chromatogram of soybean oil taken as reference containing 29 TAG starting with trilinolein and terminating with tristearin $(33,34)$. The elution sequence was the same as that reported by El-Hamdy and Perkins (35).

\section{Tocopherol Pattern}

Direct determination of tocopherols $(T)$ in oil was accomplished using Toyo-Soda-CCPm HPLC instrument. An oil sample of 10 gram was solubilizied in $\mathrm{n}$-hexane to make $10 \%$ solution and $10 \mu \mathrm{l}$ was injected onto the silica column (YMC-A-012, $6.0 \mathrm{x}$ $150 \mathrm{~mm}$ ). Isocratic elution was conducted using n-hexane: isopropyl alcohol (100: 0.5 , by volume) as mobile phase, at a flow rate of $1-2 \mathrm{ml} / \mathrm{min}$. Hitachi-650-10S fluorescence detector was used. Spectral absorption was set at excitation and emission wave lengths of 295 and $325 \mathrm{~nm}$ respectively. The conditions were optimized to elute delta-T after 10 minutes. The results were automatically recorder as peak area percentages by electronic integrator. From the peak area and the corresponding weight of each individual $T$ in the standard mixture, the weight of each individual $\mathrm{T}$ in the oil (ppm) can be calculated $(18,33)$.

\section{Whole Sterol Profile}

The prepared unsaponifiable portion of the oil $(18,36)$, was subjected to preparative TLC on silica gel $\mathrm{G}$ plates (0.5 $\mathrm{mm}$ thickness) using chloroform/ diethylether/acetic acid (95/4/1 by volume) as developing solvent. The sterol zone was located with the help of standard beta-sitosterol applied alongside the sample prior to development. The scrapped zone was thoroughly extracted with diethyl ether and the solvent was distilled off from the filtered solution.

Hewlett Packard-HP 5890A gas chromatograph, was employed for analysis using the following operating conditions: column DB-17 (0.32 mm x 15 $\mathrm{m}, 0.25 \mu \mathrm{m}$ coating) at $250^{\circ} \mathrm{C}$; detector, FID at $260^{\circ} \mathrm{C}$; injection $250^{\circ} \mathrm{C}$; carrier gas, Helium $(8,6 \mathrm{ml} / \mathrm{min})$ and split ratio, 35:1. Standard sterols mixture containing known weights of available standard sterols, was used for identification and quantitation.

\section{E. Sterol Patterns of Free and Acylated Sterols}

The subsequent free sterol (FS) and acylated sterol (AS) isolations, their derivatization into 9-nthroylnitriles (S-9-AN) and HPLC determination, were followed according to El-Mallah et al. $(33,34)$.

FS and AS were isolated from the oil by preparative TLC using n-hexane / diethylether / formic acid $(70 / 30 / 1 \mathrm{v} / \mathrm{v} / \mathrm{v})$ as developing solvent. The FS $\left(R_{f}=0.16\right)$ and AS $\left(R_{f}=0.63\right)$ were scrapped off and extracted with chloroform. Only AS were deacylated via mild alkaline hydrolysis $(0.5 \mathrm{~N} \mathrm{KOH}$ in isopropyl alcohol). The obtained FS as well as the original FS were separately derivatized into their sterol S-9-AN derivatives according to the same method mentioned above.

HPLC of S-9-AN was conducted under the following conditions: reversed phase column, ODS-1250Y, Senshu Pak (4.6 x 250 mm); detector, fluorescence; excitation and emission wave lengths set at 360 and $460 \mathrm{~nm}$; isocratic elution using acetonitrile / dichloromethane (75/25, v/v) at flow rate $1 \mathrm{ml} / \mathrm{min}$. 


\section{F. Sterylglycoside Profile of Free and Acylated Sterols}

The procedure of separation from the oil, derivatization into sterylglycoside 1-anthroylnitrile (SG-1-AN) and HPLC analysis were carried out according to El-Mallah et al. $(33,34)$.

The free sterylglycoside (FSG) and the acylated sterylglycoside (ASG) were separated from the oil by injecting the oil solution into silica gel cartridge (Sep-Pak, Waters) and were eluted with chloroform: methanol $(1: 1 \mathrm{v} / \mathrm{v})$. The mixed compounds were subsequently fractionated into pure FSG and ASG with the help of preparative TLC. Chloroform / methanol / formic acid mixture (90/15/1, v/v/v) was used as developing solvent. Only ASG was subjected to alkaline hydrolysis $(0.5 \mathrm{~N} \mathrm{KOH}$ in isopropanol) to obtain FSG. The original and obtained FSG were derivatized separately, into SG-1-AN according to the same method mentioned above.

HPLC instrument, equipped with UV detector (Toso, UV 8000) and ODS Wakosil-5, $\mathrm{C}_{18}(6.4 \mathrm{~mm} x$ $250 \mathrm{~mm}$ was used for SG-1 -AN analysis. Gradient elution with acetonitrile/dichloromethane (from 50/50 to $68 / 32 \mathrm{v} / \mathrm{v}$ ) was used. Absorption was measured at $254 \mathrm{~nm}$. It is noteworthy to mention that this method is sensitive to 0.5 nanogram of SG.

\section{RESULTS AND DISCUSSIONS}

\subsection{Fatty Acid Pattern}

The changes in fatty acid profiles in maturing rapeseed, belonging to the three varieties are shown in Table I. Generally the unsaturated fatty acids showed marked variation during maturation process.
Thus, oleic acid isomer ( $\mathrm{n}-9)$ was increasing, however linoleic and linolenic acids were decreasing as maturation proceeded.

Palmitic and stearic acids were the main saturated fatty acid constituents. It can be noticed that palmitic acid was decreasing by maturation whereas stearic acid decreased at mid maturation and then it was kept constant at full maturation stage in VA and VB whereas it slightly decreased in VC. Other fatty acids, namely, $\mathrm{C}_{20: 0}$ and $\mathrm{C}_{20: 1}$ were detected in reasonable amounts at the different maturation stages. On the other hand, $\mathrm{C}_{22: 0}, \mathrm{C}_{22: 1}$, $\mathrm{C}_{24: 0}$ and $\mathrm{C}_{24: 1}$ fatty acids were detected in minor amounts at the different stages of maturation.

It is suggested that palmitic acid as well as linoleic and linolenic acids can be converted into oleic acid via enzymatic transformations including addition of $\mathrm{C}_{2}$ units $(37,38,39)$.

\subsection{Triacylglycerol Pattern}

From the data recorded in Tables II, III and IV it can be seen that the TAG species, as determined by HPLC, showed marked variations during maturation of the different varieties of rapeseed.

From the data recorded in Table $I$ it can be seen that the major TAGs of the first variety (VA) were XLO, LLO, XOO, LOO, LOP, OOO and OOP where other TAGs were present in comparatively lower amounts, namely, XLL, XXO, LLL, XLP, LLP, XLS, LOS and OOS. Also, it was observed that XOO, LOO and $\mathrm{OOO}$ exhibit an increase in quantity as maturation proceeded, whereas XLO, LLO and LOP showed a decrease as maturation proceeded. LOS and OOP exhibited their minima, however OOS showed its maximum value at mid-maturation stage.

In the second variety (VB), LLO, XOO, LOO and OOO generally increased as maturation proceeded.

Table I

Fatty acid composition of the oils of the three varieties of rapeseed determined by GLC

\begin{tabular}{|c|c|c|c|c|c|c|c|c|c|c|c|c|c|c|}
\hline \multirow{2}{*}{$\begin{array}{l}\text { Days after } \\
\text { flowering } \\
\text { (DAF) }\end{array}$} & \multirow{2}{*}{$\begin{array}{c}\text { Content } \\
(\%)\end{array}$} & \multicolumn{13}{|c|}{ Fatty acid composition (\%) } \\
\hline & & $16: 0$ & $16: 1$ & $18: 0$ & $n-9$ & $n-7$ & $18: 2$ & $18: 3$ & 20:0 & $20: 1$ & $22: 0$ & $22: 1$ & $24: 0$ & $24: 1$ \\
\hline \multicolumn{15}{|l|}{ VA } \\
\hline $\begin{array}{l}65 \\
80 \\
95\end{array}$ & $\begin{array}{l}99.1 \\
98.7 \\
98.9\end{array}$ & $\begin{array}{l}5.4 \\
4.5 \\
4.0\end{array}$ & $\begin{array}{l}0.3 \\
0.2 \\
0.2\end{array}$ & $\begin{array}{l}2.5 \\
2.0 \\
2.0\end{array}$ & $\begin{array}{l}47.5 \\
55.1 \\
59.0\end{array}$ & $\begin{array}{l}4.3 \\
3.4 \\
3.3\end{array}$ & $\begin{array}{l}26.2 \\
21.8 \\
19.6\end{array}$ & $\begin{array}{r}10.5 \\
9.8 \\
8.8\end{array}$ & $\begin{array}{l}0.7 \\
0.6 \\
0.6\end{array}$ & $\begin{array}{l}1.6 \\
1.7 \\
1.5\end{array}$ & $\begin{array}{l}0.4 \\
0.3 \\
0.3\end{array}$ & $\begin{array}{l}0.3 \\
0.4 \\
0.3\end{array}$ & $\begin{array}{l}0.1 \\
0.1 \\
0.2\end{array}$ & $\begin{array}{l}0.3 \\
0.1 \\
0.2\end{array}$ \\
\hline \multicolumn{15}{|l|}{ VB } \\
\hline $\begin{array}{l}65 \\
80 \\
95\end{array}$ & $\begin{array}{l}97.8 \\
99.4 \\
98.9\end{array}$ & $\begin{array}{l}5.0 \\
4.3 \\
4.1\end{array}$ & $\begin{array}{l}0.3 \\
0.2 \\
0.2\end{array}$ & $\begin{array}{l}2.5 \\
2.1 \\
2.1\end{array}$ & $\begin{array}{l}48.8 \\
57.6 \\
58.9\end{array}$ & $\begin{array}{l}3.9 \\
3.2 \\
3.3\end{array}$ & $\begin{array}{l}25.2 \\
19.0 \\
18.8\end{array}$ & $\begin{array}{r}10.2 \\
9.8 \\
9.2\end{array}$ & $\begin{array}{l}0.8 \\
0.6 \\
0.6\end{array}$ & $\begin{array}{l}1.9 \\
1.8 \\
1.7\end{array}$ & $\begin{array}{l}0.3 \\
0.3 \\
0.3\end{array}$ & $\begin{array}{l}0.8 \\
0.8 \\
0.5\end{array}$ & $\begin{array}{l}0.2 \\
0.2 \\
0.2\end{array}$ & $\begin{array}{l}0.1 \\
0.1 \\
0.1\end{array}$ \\
\hline $\begin{array}{r}\text { VC } \\
65 \\
80 \\
95\end{array}$ & $\begin{array}{l}97.8 \\
99.0 \\
98.8\end{array}$ & $\begin{array}{l}5.8 \\
4.3 \\
4.3\end{array}$ & $\begin{array}{l}0.4 \\
0.3 \\
0.2\end{array}$ & $\begin{array}{l}2.4 \\
2.0 \\
1.7\end{array}$ & $\begin{array}{l}46.0 \\
56.5 \\
57.0\end{array}$ & $\begin{array}{l}5.3 \\
3.8 \\
3.1\end{array}$ & $\begin{array}{l}26.1 \\
21.0 \\
21.0\end{array}$ & $\begin{array}{r}11.1 \\
9.5 \\
9.0\end{array}$ & $\begin{array}{l}0.7 \\
0.6 \\
0.6\end{array}$ & $\begin{array}{l}1.2 \\
1.3 \\
1.8\end{array}$ & $\begin{array}{l}0.4 \\
0.3 \\
0.4\end{array}$ & $\begin{array}{l}0.1 \\
0.2 \\
0.5\end{array}$ & $\begin{array}{l}0.2 \\
0.1 \\
0.2\end{array}$ & $\begin{array}{l}0.3 \\
0.1 \\
0.1\end{array}$ \\
\hline
\end{tabular}


Table II

Triacylglycerol profile of rapeseed (VA) during seed maturation determined by HPLC

\begin{tabular}{|c|c|c|c|}
\hline $\begin{array}{l}\text { Molecule } \\
\text { species }\end{array}$ & 65 DAF & $80 \mathrm{DAF}$ & $95 \mathrm{DAF}$ \\
\hline \multicolumn{4}{|l|}{ VA } \\
\hline$X X X$ & 0.1 & - & - \\
\hline$X X L$ & 0.5 & 0.4 & 0.4 \\
\hline$X L L$ & 2.2 & 1.0 & 1.0 \\
\hline XXO & 1.4 & 1.4 & 1.5 \\
\hline XXP & 0.2 & 0.1 & 0.1 \\
\hline LLL & 2.6 & 0.9 & 0.8 \\
\hline XLO & 7.2 & 6.6 & 6.2 \\
\hline XLP & 1.0 & 0.7 & 0.8 \\
\hline LLO & 10.1 & 8.4 & 7.6 \\
\hline $\mathrm{XOO}$ & 8.0 & 9.9 & 10.9 \\
\hline LLP & 1.4 & 0.8 & - \\
\hline XLS & 2.0 & 1.6 & - \\
\hline LOO & 20.4 & 23.9 & 24.5 \\
\hline LOP & 5.6 & 5.2 & 5.0 \\
\hline XOS & 0.3 & 0.2 & 0.3 \\
\hline UNK1 & 1.4 & 1.5 & 1.3 \\
\hline 000 & 20.3 & 25.2 & 26.7 \\
\hline LOS & 2.0 & 1.5 & 1.9 \\
\hline $\mathrm{OOP}$ & 4.5 & 4.0 & 5.0 \\
\hline LSP & 0.4 & 0.2 & 0.2 \\
\hline POP & 0.9 & 0.5 & 0.4 \\
\hline UNK2 & 1.4 & 1.3 & 1.4 \\
\hline UNK3 & 1.0 & 0.6 & 0.4 \\
\hline OOS & 0.9 & 2.0 & 2.0 \\
\hline LSS & 0.7 & 0.3 & 0.2 \\
\hline UNK4 & - & 0.1 & - \\
\hline POS & 0.2 & 0.3 & 0.1 \\
\hline SPP & 0.4 & 0.2 & 0.2 \\
\hline UNK5 & 0.6 & 0.5 & 0.5 \\
\hline SOS & 0.5 & 0.3 & 0.3 \\
\hline SSP & 0.1 & 0.1 & 0.1 \\
\hline UNK6 & 0.3 & 0.2 & 0.1 \\
\hline SOA & 0.3 & - & - \\
\hline UNK7 & 0.1 & 0.1 & 0.1 \\
\hline
\end{tabular}

$\mathrm{X}=$ Linolenic; $\mathrm{O}=$ Oleic; $\mathrm{P}=\mathrm{Palmitic} ; \mathrm{L}=$ Linoleic; $\mathrm{S}=$ Stearic; $\mathrm{A}=$ Arachidic; UNK= UNKnown.

On the other side, XLO and LOP decreased as maturation was progressing. On the other side OOP decreased and then it was kept nearly constant at mid (80 DAF) and full maturation stage (95 DAF).

Concerning changes in the third variety (VC), $\mathrm{XOO}, \mathrm{LOO}$ and $\mathrm{OOO}$ showed an increase in their amounts as maturation was progressing. XLO, LLO and LOP showed marked decrease only at mid maturation stage (80 DAF) and then it was nearly kept constant at full maturation stage (95 DAF).

Generally, there are certain TAGs, namely, XOO, $\mathrm{LOO}$ and $\mathrm{OOO}$ that showed marked increase during seed maturation in the three varieties of rapeseed. On the contrary, other TAGs showed general decrease, as maturation was progressing, such as XLO and LOP.
Table III

Triacylglycerol profile of rapeseed (VB) during seed maturation determined by HPLC

\begin{tabular}{|c|c|c|c|}
\hline $\begin{array}{l}\text { Molecule } \\
\text { species }\end{array}$ & 65 DAF & 80 DAF & $95 \mathrm{DAF}$ \\
\hline \multicolumn{4}{|l|}{ VB } \\
\hline$X X X$ & 0.1 & 0.1 & - \\
\hline$X X L$ & 0.3 & 0.2 & 0.3 \\
\hline XLL & 1.1 & 1.0 & 0.9 \\
\hline $\mathrm{XXO}$ & 2.0 & 1.9 & 1.8 \\
\hline XXP & 0.1 & 0.2 & 0.2 \\
\hline LLL & 0.9 & 0.8 & 0.6 \\
\hline XLO & 7.0 & 6.5 & 6.0 \\
\hline XLP & 1.5 & 1.0 & 0.7 \\
\hline LLO & 6.0 & 7.0 & 7.5 \\
\hline $\mathrm{XOO}$ & 10.0 & 10.5 & 11.5 \\
\hline LLP & 1.0 & 1.0 & - \\
\hline XLS & 2.3 & 2.4 & 2.0 \\
\hline LOO & 18.0 & 19.0 & 21.4 \\
\hline LOP & 7.5 & 6.0 & 5.0 \\
\hline XOS & 0.7 & 0.5 & 0.3 \\
\hline UNK1 & 1.7 & 1.7 & 1.7 \\
\hline 000 & 22.0 & 23.5 & 25.5 \\
\hline LOS & 2.5 & 2.1 & 1.8 \\
\hline OOP & 5.0 & 4.5 & 4.5 \\
\hline LSP & 0.5 & 0.4 & 0.2 \\
\hline POP & 1.2 & 1.0 & 0.6 \\
\hline UNK2 & 1.8 & 1.4 & 1.4 \\
\hline PPP & 0.2 & 0.2 & - \\
\hline UNK3 & 0.2 & 0.7 & 0.8 \\
\hline OOS & 2.9 & 2.6 & 2.3 \\
\hline LSS & 0.5 & 0.5 & 0.5 \\
\hline UNK4 & 0.1 & 0.3 & 0.3 \\
\hline POS & 0.7 & 0.6 & 0.4 \\
\hline SPP & 0.4 & 0.4 & 0.4 \\
\hline UNK5 & 0.8 & 0.8 & 0.7 \\
\hline SOS & 0.6 & 0.5 & 0.4 \\
\hline SSP & 0.3 & 0.2 & 0.1 \\
\hline UNK6 & - & 0.3 & 0.1 \\
\hline SOA & 0.1 & 0.1 & - \\
\hline UNK7 & - & 0.1 & 0.1 \\
\hline
\end{tabular}

$\mathrm{X}=$ Linolenic; $\mathrm{O}=$ Oleic; $\mathrm{P}=$ Palmitic; $\mathrm{L}=$ Linoleic; $\mathrm{S}=$ Stearic; $A=$ Arachidic; UNK= UNKnown.

\subsection{Tocopherol Patterns}

Changes in the total amounts of tocopherols and the tocopherol composition are illustrated in Table V. Total tocopherols was markedly increasing during maturation stages in the three varieties however, VB showed a comparatively higher tocopherol content at different maturation stages than the other two varieties. Concerning the changes in the composition of tocopherol patterns, alpha-tocopherol was gradually decreasing as maturation proceeded while gamma-tocopherol was gradually increasing at mid-maturation stage whereas it markedly increased at full maturation stage.

Meanwhile, beta-tocopherol was detected in small amounts but it disappeared at full maturation 
Table IV

Triacylglycerol profile of rapeseed (VC) during seed maturation determined by HPLC

\begin{tabular}{|c|c|c|c|}
\hline $\begin{array}{l}\text { Molecule } \\
\text { species }\end{array}$ & 65 DAF & $80 \mathrm{DAF}$ & 95 DAF \\
\hline \multicolumn{4}{|l|}{ vc } \\
\hline$X X X$ & 0.1 & 0.1 & - \\
\hline$X X L$ & 0.8 & 0.3 & 0.5 \\
\hline XLL & 2.5 & 1.2 & 1.0 \\
\hline XXO & 1.8 & 1.4 & 1.5 \\
\hline XXP & 0.2 & 0.1 & 0.1 \\
\hline LLL & 2.5 & 1.2 & 1.0 \\
\hline XLO & 7.5 & 6.5 & 6.6 \\
\hline XLP & 1.3 & 0.9 & 0.8 \\
\hline LLO & 9.6 & 8.4 & 8.4 \\
\hline $\mathrm{XOO}$ & 7.8 & 10.0 & 11.0 \\
\hline LLP & 1.8 & 0.9 & 0.9 \\
\hline XLS & 2.5 & 2.2 & - \\
\hline LOO & 18.6 & 20.5 & 23.5 \\
\hline LLS & 1.0 & - & - \\
\hline LOP & 6.0 & 5.5 & 5.3 \\
\hline XOS & 0.3 & 0.3 & 0.3 \\
\hline UNK1 & 1.4 & 1.5 & 1.7 \\
\hline 000 & 18.0 & 24.5 & 25.1 \\
\hline LOS & 2.9 & 2.1 & 1.6 \\
\hline $\mathrm{OOP}$ & 5.0 & 4.7 & 4.5 \\
\hline LSP & 0.4 & 0.2 & 0.2 \\
\hline POP & 0.6 & 0.5 & 0.4 \\
\hline UNK2 & 1.2 & 1.6 & 1.5 \\
\hline PPP & & & \\
\hline UNK3 & 0.9 & 0.8 & 0.6 \\
\hline OOS & 2.2 & 2.2 & 1.8 \\
\hline LSS & 0.2 & 0.1 & 0.3 \\
\hline UNK4 & - & 0.3 & 0.3 \\
\hline POS & 0.6 & 0.2 & 0.3 \\
\hline SPP & 0.3 & 0.3 & 0.3 \\
\hline UNK5 & 0.7 & 0.6 & 0.6 \\
\hline SOS & 0.4 & 0.3 & 0.3 \\
\hline SSP & 0.2 & 0.2 & 0.1 \\
\hline UNK6 & 0.4 & 0.3 & 0.3 \\
\hline SOA & 0.1 & 年 & \\
\hline UNK7 & 0.2 & 0.1 & 0.1 \\
\hline
\end{tabular}

$\mathrm{X}=$ Linolenic; $\mathrm{O}=$ Oleic; $\mathrm{P}=\mathrm{Palmitic} ; \mathrm{L}=$ Linoleic; $\mathrm{S}=$ Stearic; $\mathrm{A}=$ Arachidic; $\mathrm{UNK}=\mathrm{UNKnown}$.

stage in VA and VC varieties. Whereas in VB variety, it was detected only at early maturation stage(65DAF). On the other side, delta-tocopherol appeared only as minor component at full maturation stage in the three rapeseed varieties.

It is clear that tocopherols acquire the oil more oxidative stability particulary for those oils enriched in linolenic acid (40). However, it was reported that there is no direct biochemical link between the synthesis of tocopherol and the storage lipids $(41,42)$.

\subsection{Sterols Pattern}

The characteristic sterol for Brassica napus, namely, brassicasterol showed some marked
Table V

Tocopherol composition of the oils of the three rapeseed varieties determined by HPLC

\begin{tabular}{|c|c|c|c|c|c|}
\hline \multirow{2}{*}{$\begin{array}{l}\text { Days after } \\
\text { flowering } \\
\text { (DAF) }\end{array}$} & \multirow{2}{*}{$\begin{array}{c}\text { Total } \\
\text { tocopherol } \\
\text { ppm }\end{array}$} & \multicolumn{4}{|c|}{ Tocopherol composition (\%) } \\
\hline & & Alpha-T. & Beta-T. & Gamma-T. & Delta-T. \\
\hline \multicolumn{6}{|l|}{ VA } \\
\hline $\begin{array}{l}65 \\
80\end{array}$ & $\begin{array}{l}140 \\
280\end{array}$ & $\begin{array}{l}76.2 \\
65.6\end{array}$ & $\begin{array}{l}9.0 \\
7.3\end{array}$ & $\begin{array}{l}14.8 \\
27.1\end{array}$ & - \\
\hline 95 & 570 & 25.7 & - & 73.4 & 0.9 \\
\hline \multicolumn{6}{|l|}{ VB } \\
\hline 65 & 190 & 72.0 & 8.0 & 20.0 & - \\
\hline 80 & 580 & 34.0 & - & 66.0 & - \\
\hline 95 & 620 & 28.6 & - & 70.1 & 1.3 \\
\hline \multicolumn{6}{|l|}{ vC } \\
\hline 65 & 150 & 71.0 & 10.5 & 18.5 & - \\
\hline 80 & 270 & 52.0 & 6.3 & 41.7 & - \\
\hline 95 & 550 & 31.3 & - & 67.7 & 1.0 \\
\hline
\end{tabular}

T.: Tocopherol.

Table VI

Sterol pattern of the oils of the three rapeseed varieties determined by GLC

\begin{tabular}{|c|c|c|c|c|c|c|c|}
\hline \multirow{2}{*}{$\begin{array}{l}\text { Days after } \\
\text { flowering } \\
\text { (DAF) }\end{array}$} & \multirow{2}{*}{$\begin{array}{c}\text { Content } \\
(\%)\end{array}$} & \multicolumn{6}{|c|}{ Whole sterol composition (\%) } \\
\hline & & $\begin{array}{l}\text { Brassica- } \\
\text { Sterol }\end{array}$ & $\begin{array}{l}\text { Campe- } \\
\text { Sterol }\end{array}$ & $\begin{array}{l}\text { *Unknown } \\
\text { Sterol }\end{array}$ & $\begin{array}{c}\text { 5-stigma- } \\
\text { Sterol }\end{array}$ & $\begin{array}{l}\beta \text {-Sito- } \\
\text { Sterol }\end{array}$ & $\begin{array}{c}\text { Isofuco- } \\
\text { Sterol }\end{array}$ \\
\hline \multicolumn{8}{|l|}{ VA } \\
\hline 65 & 0.9 & 10.2 & 30.1 & 2.2 & 3.1 & 52.5 & 1.9 \\
\hline 80 & 0.8 & 12.8 & 29.2 & 2.1 & 2.4 & 51.3 & 2.2 \\
\hline 95 & 0.7 & 11.4 & 32.0 & 2.5 & 1.5 & 49.9 & 2.7 \\
\hline \multicolumn{8}{|l|}{ VB } \\
\hline 65 & 1.2 & 10.1 & 31.0 & 2.6 & 3.0 & 50.0 & 3.3 \\
\hline 80 & 0.9 & 12.4 & 29.8 & 2.0 & 1.8 & 50.8 & 2.2 \\
\hline 95 & 0.8 & 13.2 & 29.0 & 2.8 & 2.1 & 50.6 & 2.3 \\
\hline \multicolumn{8}{|l|}{ VC } \\
\hline 65 & 1.0 & 7.6 & 30.9 & 2.9 & 3.5 & 52.2 & 2.9 \\
\hline 80 & 0.9 & 10.1 & 30.0 & 3.4 & 2.0 & 52.0 & 2.5 \\
\hline 95 & 0.8 & 13.4 & 29.0 & 2.0 & 2.5 & 51.1 & 2.0 \\
\hline
\end{tabular}

* Unknown sterol that may stand for lophenol.

variation during maturation process in the three varieties (Table $\mathrm{VI}$ ). Thus it showed a maximum value at mid maturation stage in VA and at full maturation stage in both VB and VC varieties.

Campesterol exhibited higher values at early stage of maturation in VB and VC and it decreased as maturation was progressing, where it reached its maximum value at full maturation stage in VA.

An unknown sterol, probably identified as lophenol, showed higher value at full maturation stage in VA and VB and at mid maturation stage in VC. Lophenol seems to be one of the intermediates in the sterol biosynthesis. 
5-stigmasterol showed generally gradual decrease as maturation was progressing in VA whereas it showed no regular change in the other two varieties, VB and VC.

Beta-sitosterol showed a decrease during maturation in VA, whereas no marked variation in the same sterol was observed in VB. In VC, beta-sitosterol was nearly constant at early and mid-maturation stages but it decreased in quantity at full maturation stage.

Isofucosterol generally decreased as maturation proceeded in VB and VC, however it increased gradually in VA.

From the above mentioned results, it can be noticed that there are marked variations in the whole sterols patterns in the three varieties during maturation process and the varietal changes can also be presented as follows:

- Lower brassicasterol level in VA at full maturation and higher brassicasterol in both VB and VC. However VC exhibited comparatively lower brassicasterol at early maturation stage.

- Campesterol showed a maximum value only in VA but at full maturation stage.

- Isofucosterol reached its optimum value at early maturation stage only in VB .
- An unknown sterol was proved to be lophenol by mass spectral analysis (43) and it showed its maximum value at mid maturation stage only in VC.

\subsection{Sterol Lipids}

Sterol Lipids, included four sterol groups, glycosidic and non-glycosidic in the form of free and acylated forms, namely, free and acylated sterols and sterylglycosides.

\subsection{Free and Acylated Sterols}

In VA, isofucosterol, brassicasterol, campe / stigmasterol and beta-sitosterol were detected in the free and acylated sterol fractions showing marked variation during maturation (Table VII). In free sterol (FS) fraction, isofucosterol, was not detected at early stage of maturation and showed very slight variation during maturation, whereas brassicasterol and the unseperable pair of campe/stigmasterol increased as maturation proceeded. However, beta-sitosterol decreased as maturation proceeded showing an opposite behavior to brassicasterol and campe / stigmasterol.

Table VII

Free and acylated sterol profiles of the oils of the three rapeseed varieties determined by HPLC

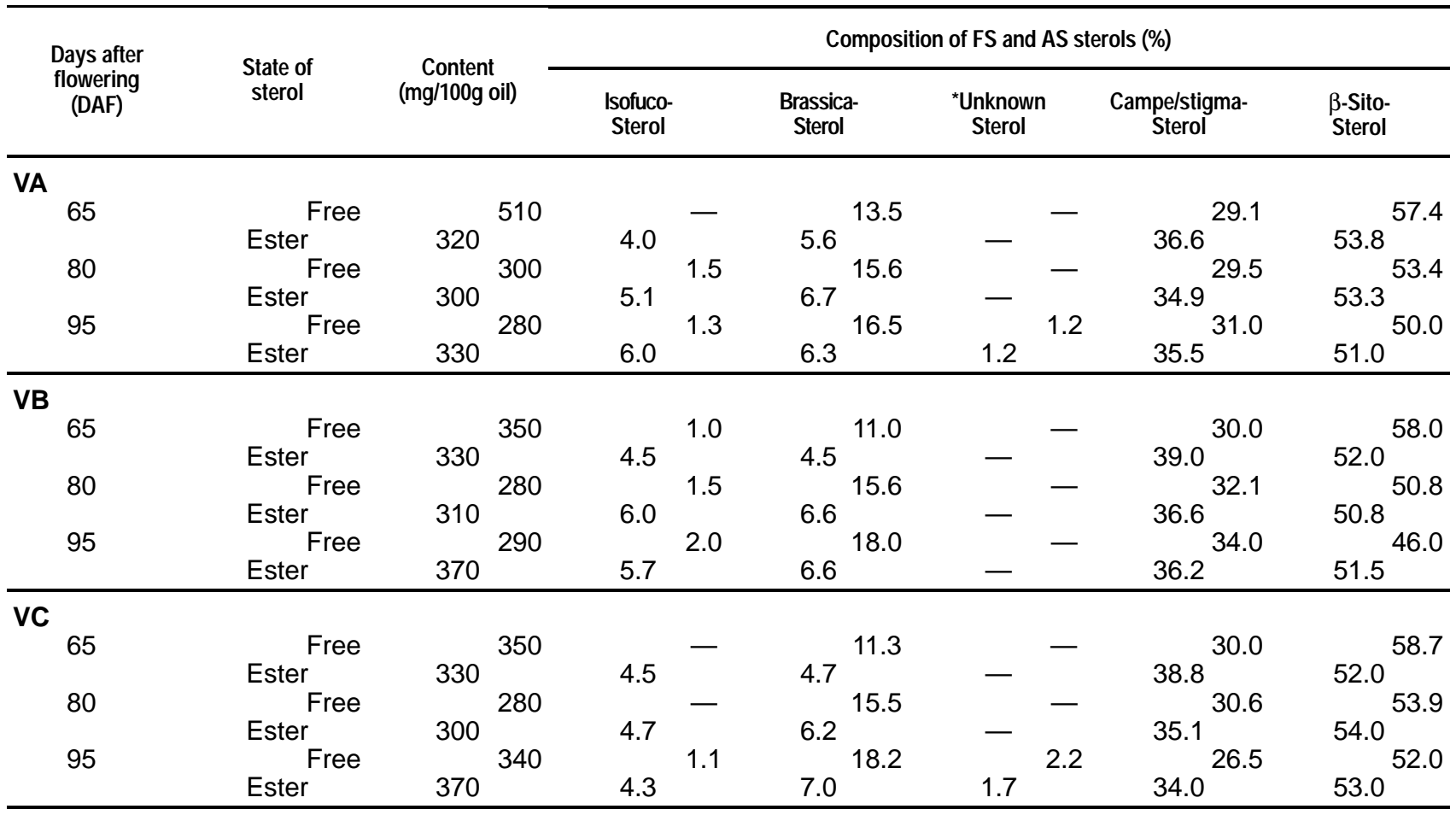

FS: Free sterol; AS: Acylated sterol.

* Unknown sterol that may stand for cholesterol. 
In acylated fraction (AS), isofucosterol and brassicasterol were detected in somewhat lower values whereas campe/stigmasterol and betasitosterol were found in much higher levels. Isofucosterol, and brassicasterol were generally increased as maturation was progressing, whereas campe/stigmasterol and $\beta$-sitosterol were generally decreased by maturation.

In FS fraction of VB isofucosterol, brassicasterol and campe/stigmasterol showed gradual increase by maturation, however, beta-sitosterol behaved in an opposite manner. On the other side, isofucosterol, and brassicasterol in the AS fraction were at their comparatively lower values at early maturation stage and they generally increased by maturation. Campe/stigmasterol and beta-sitosterol were present at their higher levels at this stage and generally decreased as maturation was progressing.

In VC, the FS fraction contained no isofucosterol at early and mid maturation stage, however it appeared only at full maturation stage. Brassicasterol showed a very marked variation during maturation thus it increased as maturation was progressing. However campe/stigmasterol increased slightly at mid maturation and then it decreased to reach its minimum value at full maturation stage. On the other side, beta-sitosterol behaved in an opposite manner to brassicasterol, thus it decreased as maturation was progressing.

In the AS fraction, isofucosterol showed no marked variation, however brassicasterol increased as maturation proceeded. Campe/stigmasterol decreased markedly at mid maturation stage and then slightly decreased at full maturation stage, whereas beta-sitosterol reached its maximum value at mid-maturation stage (80 DAF).

Other unknown component of sterol, which may stand for cholesterol, appeared only as minor component in VA and VC at full maturation stage in the FS and AS fractions.

\subsection{Free and Acylated Sterylglycoside}

In VA isofucosterylglycoside, brassicasterylglycoside, campe/stigmasterylglycoside and beta-sitosterylglycoside were detected in the free and acylated sterylglycoside fractions showing marked variation during maturation (Table VIII). In free sterylglycoside (FSG), isofucosterylglycoside (isofuco-SG) and avena-SG were detected only at full maturation stage, whereas brassica-SG and campe/stigma-SG showed marked variations during maturation, thus brassica-SG showed its maximum value at mid maturation stage then it decreased at full maturation

Table VIII

Free and acylated sterylglycoside profiles of the oils of the three rapeseed varieties determined by HPLC

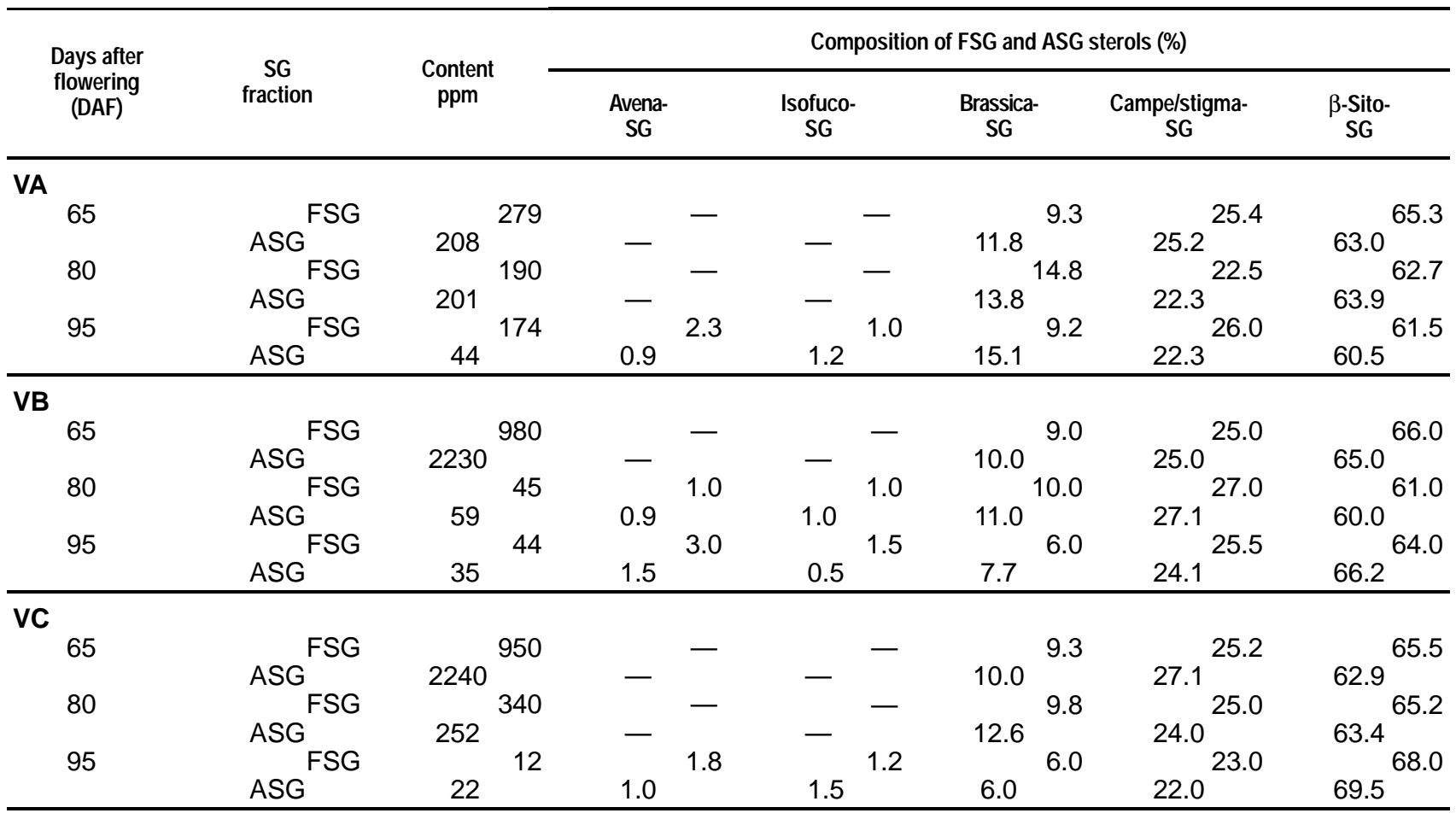


stage, whereas campe/stigma-SG exhibited its maximum value at full maturation stage. However beta-sito-SG decreased as maturation was proceeding showing a different behaviour to brassica-SG and campe/stigma- S G.

In acylated sterylglycoside (ASG) of VA, certain changes were observed, low amounts of isofuco-SG and avena-SG were detected only at full maturation stage. Brassica-SG exhibited lower amounts than campe/stigma-SG and beta-sito-SG and it increased by maturation. Campe/stigma-SG decreased by maturation till mid maturation stage then it was kept unchanged. Whereas beta-sito-SG showed the highest value of ASG fraction and it increased slightly at mid maturation stage then decreased to reach its minimum value at full maturation.

In FSG of VB, avena-SG and isofuco-SG were firstly appeared at mid maturation and then they increased as maturation was progressing. Brassica-SG and campe/stigma- SG increased by maturation to reach their maximum values at mid maturation stage then they decreased at full maturation. On the other hand beta-sito-SG behaved in an opposite manner to both brassica-SG and campe/stigma SG.

In ASG fraction of VB avena-SG and isofuco-SG were not detected at early stage of maturation. On the other hand avena-SG was markedly increased at full maturation stage whereas isofuco-SG decreased to its half amount at full maturation. Brassica-SG and campe/stigma-SG increased by maturation at mid maturation stage then it markedly decreased at full maturation. On the other side beta-sitosterol behaved in an opposite manner.

In VC, the FSG fraction contained no avena-SG and isofuco-SG at early and mid maturation stages, however they appeared only at full maturation stage. Brassica-SG showed marked variation during maturation, thus it slightly increased at mid maturation stage then decreased at full maturation. However, campe/stigma-SG and B-sito-SG behaved similarly, showing no change, until mid maturation stage then they behaved in an opposite manner at full maturation stage.

In ASG fraction of VC avena-SG and isofuco-SG were detected only at full maturation stage. Brassica-SG increased at mid maturation stage then greatly decreased at full maturation. Campe/ stigma-SG decreased as maturation was progressing whereas beta-sito-SG behaved in an opposite manner.

\section{CONCLUSION}

Although there are some varietal similarities and differences in compositional changes of some lipids, some unique variations were observed in one variety rather than the others. These variations may be due to certain genetically differences.

Concerning the changes in certain TAG molecular species in V.B, LLO increased as maturation was progressing, however it decreased generally in the other two varieties. On the other side, LOS and OOP in VA decreased at the mid maturation period then increased whereas they decreased as maturation was progressing in the other two varieties. POP decreased as maturation was proceeding in the three varieties whereas it was present in larger quantities at the early and mid maturation stages in VB. In addition, LSS was present in higher quantity in $V A$ at the early maturation stage than in the other two varieties. Glycerides containing $\mathrm{XOO}, \mathrm{LOO}$ and OOO showed gradual increase in the three varieties as maturation proceeds however glycerides containing linoleic and linolenic acid decrease. Therefore, it can be concluded that these changes may be due to biochemical conversions into oleic acid via enzymatic hydrogenation $(37,38)$.

With reference to changes in tocopherol composition of the three varieties, marked variation in tocopherol constituents were observed. In the three varieties, namely, VA, VB and VC alpha-tocopherol decreased clearly by maturation. Beta-tocopherol decreased at mid-maturation stage in VA and VC and disappeared at full maturation stage; the tocopherol appeared at early maturation stage in VB. Gamma-tocopherol increased markedly in the three varieties, in an opposite manner with alpha-tocopherol, as maturation was progressing. On the other side, delta-tocopherol was detected in minor quantity only at full maturation stage in the three maturing seeds.

It can be concluded that alpha-tocopherol may be possibly converted into gamma-tocopherol during maturation via S-adenosyl methionine (SAM) responsible for removing one methyl group $(38,44,45)$.

With reference to the changes in sterols of the four sterol lipids, certain varietal changes occurred in the free and acylated sterols (FS and AS) of the three rapeseed varieties. Isofucosterol in FS fraction was not detected in early maturation stage in VA, however it appeared only at full maturation stage of the maturing VC. In acylated sterol fraction (AS) of $V A$, isofucosterol showed regular increase as maturation was proceeding. An unknown sterol was detected in both FS and AS fractions only at full maturation stage in VA and VC varieties. However it did not appear during any maturation stage in VB. This sterol may stand for cholesterol. On the other hand, betasitosterol of the FS fraction in VB was significantly lower at full maturation stage compared to the other two varieties.

Concerning changes in sterols of acylated sterylglycosides (ASG), brassica-SG showed its 
maximum value at full maturation in VA, however it reached a minimum value at full maturation stage in the other two varieties. Unlike the other two varieties, VB showed a maximum value of campe-SG/ stigma-SG in the ASG fraction at mid maturation stage, in VA and VC it generally decreased as maturation was proceeding.

Marked variation of sterols in maturing seeds manifested themselves only in the whole sterols profile of the three rape varieties. Accordingly, specific variations can be observed in each of the three varieties.

Generally, these characteristic varietal changes in certain lipid components in one variety may help, to some extent, to distinguish one variety from the other at any maturation stage. From the biochemical approaches mentioned above, it can be noticed that conversion-interconversion processes may occur at different rates in one variety than the other.

\section{REFERENCES}

1. Weete, J.D. and Maneley, R.C. Changes in lipids associated with Soybean seed development. J. Ala. Acad.Sci. 50 (1), (1979) 35-46.

2. Kajimoto, G. ; Yoshida, H.; Shibahara, A. and Yamashoji, S. Changes in the composition of fatty acids, tocopherols and gossypol in each part of cottonseed during maturation. Agric.Biol. Chem., 54(5),(1980) 353-356.

3. Sukhija, P.S.; Borthakur, A. and Bhatia, I.S. Effect of irrigation on lipid biosynthesis in maturing sunflower seeds. J. Sci. Food Agri., 31(3), (1980) 225-228.

4. Kajimoto, G.; Tsutsui, Y. and Yoshida, H. Changes in constituents and fatty acid composition of glycerophospholipids in cottonseeds during maturation. Nippon Nogeikagaku Kaishi, 55(1), (1981) 31-36.

5. Kajimoto, G.; Shibahara, A. and Yamasshoji, S. Changes in the contents and composition of lipids, fatty acids, tocopherols and sterols in Soybean seed during maturation. J. Jap. Soc. Nutro. Food. Sci., 35(5), (1982) 345-350.

6. Kajimoto, G. and Hasebse, A. Composition of fatty acid and tocopherol in various parts of some vegetable oilseed. J. Jap. Soc.Nutr. Food. Sci. 35(4), (1982) 291-296.

7. Kajimoto, G. ; Yoshida, H.; Shibahara, A. and Yamashoji, S. Changes in the composition of fatty acids and tocopherols of cottonseed during maturation. Agric. Biol. Chem., 56(6), (1982) 445449.

8. Kajimoto, G. and Shibahara, A. Changes in 4,4 dimethyl sterol compositions in some oil seeds during maturation. J.Jap.Soc.Nutr. Food Sci., 36(6), (1983) 499-505.

9. Kajimoto, G. and Hotsuta, H. Changes in the contents and compositions of lipids, fatty acids, tocopherols and sterols in sunflower seed during maturation. J. Jap. Oil Chemist's Soc., 32(3), (1983) 170-174.

10. Monga, P.K.; Munshi, S.K. and Sukija, P.S. Lipid biosynthesis in the developing sunflower (Helianthus annuus L.) seeds. Plant Sci.Lett., 31(2-3), (1983) 311-321.

11. Gupta, S.K. and Wagle, D.S. $17^{\text {th }}$ world congress of international society for fat research, New Delhi, India (1984) pp.23-24.

12. Samui, R.C. and Ghosh, A. $17^{\text {th }}$ world congress of international society for research, New Delhi, India (1984) abstracts of paper pp. 25.

13. Kajimoto, G.; Yoshida, H. and Shibahara, A. Contents and composition of free sterols and sterol esters in cotton and sunflower seeds during maturation. $J$. Jap. Soc.Nutr. Food Sci., 38(3), (1985) 185-189.

14. Lotti.,G.; Paradossi, G. and Marchini, F. Formation of glycerides during maturation of Glycin max. (L.) Merr Agrochimica, 30(6),(1986) 400-510.

15. Lotti,G.; Navari-IZZO, F.; Izzo, R. and Quartacci, M.F. Fatty acid and phospholipids during the early stages of seed formation in sunflower. Agrochimica, 31(3), (1987) 275-286.

16. Whitaker BD. Changes in the steryl lipid content and composition of tomato fruit during ripening. Photochemistry 27(11),(1988) 3411-3416.

17. Kumar, RLR.; Seetharam, A. and Virupakshappa, K. Changes in seed weight, oil and moisture content during development and maturation of seeds in sunflower. J. of Oil seeds Research, 9(1), (1992) 150-153.

18. El-Shami, M.S.; Hassanein, M.M.; Murui, T. and El-Mallah Hassan, M. Studies on changes in patterns of fatty acids, sterols and tocopherols of oil during seed maturation of oil crops. Part 1. Sunflower seeds. Grasas y Aceites 45(4),(1994) 227-231.

19. Triboi-Blondel-AM. and Riballier-D. Changes in rapeseed composition during maturation. Physiologie-et-elaboration-durendement-du-colza-d 'hiver. 1988, 140-142; supplement to Informations Techniques, CETIOM No. 103.

20. Roy, NN and Tatt, AW. Development of near-zero linolenic acid (18:3) Lines of rapeseed (Brassica napus L.). Zeit Schrift Pflanzen zu Chtung 96 (3), (1986) 218-223.

21. Silver, TG; Ro Chester, CP; Bishop, D.G and Harris, HC. Unsaturated fatty acid synthesis during the development of isolated sunflower (Helianthus annul.) seeds. J. of Experimental Botany 35(159), (1984) 1507-1514.

22. Kallio-H; Johansson, A. and Oksman, P. Composition and development of turnip rapeseed (Brassica campestris) oil triacylglycerols at different stages of maturation. J. of Agricultural and Food Chemistry 39 (10), (1991) 1752-1756.

23. Chernenko, TV; Glushenkova, Al; Umarov, AA and Abul'tarova-GS. Kinetics of the level of lipids in a cotton plant of variety 6524s during maturation. Chemistry of Natural Compounds 29 (3), (1994) 300-302.

24. Gupta,Sk ; Kumar, P. and Gaur, A. Lipids content and fatty acid profile of various oilseeds during seed development. Annals of Biology Ludhiana 7 (2), (1999) 191-200.

25. Pandey, SS. and Subrahmanyam, VVR. Lipid changes in maturing and germinating cottonseeds. Phytochemistry 27 (11), (1988) 3405-3409.

26. Deng- $X$ and Scarth-R. Temperature effects of fatty acid composition during development of low linolenic oilseed rape (Brassica napus $L$ ). JAOCS 75 (7), (1998) 759-766.

28. Harris, JF and Norton G. Biochemical aspects of oil deposition in developing rapeseed. Proceedings of 
the $5^{\text {th }}$ International Rapeseed Conference. Volume 2 1979, 16-20.

29. Huang, SQ. Preliminary investigation of the differences in the composition changes of fat and fatty acids in developing rapeseeds. Scientia Agricultura Sinica 3 (1980), 47-51.

30. Diepenbrock, W. and Geisler, G. Compositional changes in developing pods and seeds of oilseed rape (Brassica napus $L$.) as affected by pod position on the plant. Cand. J. of Plant Sci. 59 (3), (1979), 819-830.

31. Jaarsma-J; Bruin-B-de; De-Bruin-B; Quinn-PJ (ed.); Harwood-JL, (ed.). Fatty acid composition at position Sn-2 of seed oil triacylglycerols in high and low erucic acid varieties of Brassica napus $L$. at different stages of seed development. Plant lipid Biochemistry, Structure and Utilization. Proceedings of the ninth international symposium on plant lipids, wye college, kent, July, 1990, 33-35.

32. Christie, W.W. Lipid analysis: the preparation of volatile derivatives of lipids. Chapter 4, 85-102, Pergamon press (1973).

33. El-Mallah, M. Hassan ; Murui T. and El-Shami, S. Detailed studies on seed oil of salicornia SOS-7 cultivated at the Egyptian border of Red Sea. Grasas y Aceites 45(6) (1994) 385-389.

34. El-Mallah, M. H.; Murui T. and El-Shami, S. New trends in determining the authenticity of corn oil. Grasas y Aceites 50 (1) (1999) 7-15.

35. El-Hamdy, A.H. and Perkins, E.G. High performance reversed phase chromatography of natural triglyceride mixtures: Critical pair separation. J.Am. Oil. Chemist's Soc. 58, (1981) 867-872.

36. AOCS. Tentative methods of analysis. $2^{\text {nd }}$ Edition, Chicago, (1987).

37. Edwards, N.A. and Hassall, K.A. Lipid metabolism in Biochemistry and physiology of the cell MC Graw-Hill Book company (UK) limited (1980) pp 193-274.
38. Hess, D. Biological oxidation and fats in plant physiology. Springer-Verlag Berlin Heidelberg New York (1975) pp 74-98.

39. Minar Mohamoud; M. Hassanein (1991). Changes in the content and composition of lipids during maturation of soybean and sunflower seeds. Submitted for the Degree of M.Sc., University of Ain Shams, Faculty of Science, Cairo, Egypt.

40. Jung, M., and D. Min. Effects of $a-\gamma$ and $\delta$ Tocopherols on Oxidative Stability of Soybean oil. $J$. Food Sci. 5, (1990) 1464-1465.

41. Soll, J. - Tocopherol and plastoquinone synthesis in chloroplast membranes, in Plant cell membranes, edited by L. Packer and R, Douce, Academic press, San Diego, 1987, Vol. 148, pp. 383-392.

42. David, D.; Chris V. and Jan H. Tocopherols on breeding lines and effects of planting location, fatty acid composition, and temperature during development. JAOCS 3(76), (1999) 349-355.

43. Minar Mahmoud, M. Hassanein (1996). Studies on biochemical changes in lipid of some maturing and germinating oilseeds. Submitted for the Degree of Ph.D., University of Ain Shams, Faculty of Science, Cairo, Egypt.

44. Waller, G.R. Metabolism of plant terpenoids. In progress in the Chemistry of fats and other lipids Vol. 10 part 2, (1967) edited by R.T. Holman, Pergamon Press.

45. Goodwin, TW. Biosynthetic pathway in higher plants. J. B. Pridham and T. Swain eds. P.57 (1965) London: Academic press. 